\title{
EFFECT OF EXPERIENTIAL QUALITY AND EXPERIENTIAL SATISFACTION ON REVISIT INTENTION IN LAKE TOBA
}

\author{
Endang Sulistya RINI ${ }^{1 *}$ \\ Beby Karina Fawzeea SEMBIRING ${ }^{2}$ \\ Yeni $A B S A H^{3}$
}

\begin{abstract}
Received: January 2021 | Accepted: February 2021 | Published: April 2021
Please cite this paper as: Rini, E.S., Sembiring B.K.F., Absah, Y. (2021) Effect of experimental quality and experimental satisfaction on revisit intention in Lake Toba, Holistica Journal of Business and public Administration, Vol.12, Iss.1, pp.41-48
\end{abstract}

\begin{abstract}
The purpose of this study is to look at the influence of experiential quality on revisit intention through experiential satisfaction. The population in this study is tourists, of an unknown population number, who have already visited Lake Toba. Based on Malhotra's theory, with the number of respondents of 324, the sampling method used is accidental sampling. The data analysis in this study is descriptive analysis and statistical analysis of PLS-SEM using Smart-PLS software. The results of this study show that experiential quality has a positive and significant effect on experiential satisfaction variables. Experiential quality has a positive and significant effect on variable revisit intention, and experiential satisfaction has a positive and significant effect on variable revisit intention through experiential satisfaction. The implication of this research is that experience is an important thing to research where good and bad experiences can make tourists revisit to the visited tourist attractions.
\end{abstract}

Keywords: Experiential Quality; Experiential Satisfaction; Revisit Intention

\section{Introduction}

Tourism is a new type of industry that is able to accelerate economic development along with providing jobs, growing income, including living standards, and to incentivise other productive sectors. As a complex sector, tourism also connects with classic industries such as handicraft and souvenir industries. Lodging and transportation are also seen as

\footnotetext{
${ }^{1}$ Faculty of Economics and Business, Universitas Sumatera Utara, Indonesia, endang.sulistya@usu.ac.id.

* Corresponding author.

${ }^{2}$ Faculty of Economics and Business, Universitas Sumatera Utara, Indonesia, beby@usu.ac.id.

${ }^{3}$ Faculty of Economics and Business, Universitas Sumatera Utara, Indonesia, yeni.absah@usu.ac.id.
} 
examples of sectors of this industry. Indonesia ranks $28^{\text {th }}$, as the most visited country by tourists, with 9.4 million visits in 2018 according to the World Tourism Organization.

North Sumatra, where the centre of its provincial government is located in Medan as the capital city, has many interesting natural attractions, one of which is Lake Toba. A lake with relies on local folklores. One of the most famous tourist attractions in Indonesia, the volcanic Lake Toba boasts majestic hills and sturdy, shady trees that bring fresh, cool air. Such fascinating natural features around the lake create comfort for the tourist to enjoy the scenic sunset in the afternoon. The Indonesian government has made a brilliant decision for Lake Toba as one of the priority tourism destinations.

Travelling to Lake Toba from Medan city is quite close. Tourists normally drive for approximately 4 hours, but the latest addition of the Silangit Airport enables tourists to directly reach the touristic area of Lake Toba and cross the lake by boat in approximately 45 minutes. This upgraded infrastructure has helped to increase the number of tourists. However, the presurvey data on Lake Toba showed that the lake has changed. Most respondents expressed their disappointment over the poor experience with dirty lake water and scattered garbage, badly maintained roads, transportation, and accommodation. Revisit intention can be influenced by experience because it can be crucial for the prosperity of the tourism industry in term of tourist attractions visits. In this research, experience is subdivided into Experiential Quality and Experiential Satisfaction. Tourists visiting Lake Toba will have their own experience during their vacation. The experience determines whether the tourists will re-select Lake Toba as one of the tourist destinations, which can be influenced by their experience.

\section{Literature Review}

\subsection{Experiential Quality}

As stated by to Chen and Chen (2010), the quality of the experience itself focuses on the quality of performance in the tourism aspect where the quality of the experience is seen from the perceived results of the participation of tourists in tourism activities. Previous research has examined many aspects of service quality in tourism providers, but nowadays researches have expanded their focus on not only the quality of service, but also the experience felt by tourists. In general, the quality felt by tourists is related to the experience that tourists feel during their visit process compared to the services provided by the tourism site itself. Crompton and Love (1995) define the quality of the experience does not only affected by the performance of tourism service providers, yet it is also affected by the characteristics of the visitors in the site. The evaluation of the quality of the experience aim to pinpoint the reflection of travellers' attitude, as well as conceptual towards the technical and functional benefits of the external service environment provided by service-providers (Corinin and Talyor, 1994). 


\subsection{Experiential Satisfaction}

Satisfaction is a feeling of pleasure that tourists feel that occurs from travel experiences related to product or service features that are in accordance with the expectations and desires of tourists in travel (Severt et al. 2007). Satisfaction is made by comparing the expectations of tourists before and after their trip. Tourists are satisfied when the experience exceeds expectations. However, if tourists are unhappy, it will be dissatisfaction (Chen and Chen, 2010). The concepts for measuring traveller's satisfaction with destination is different with measurement of satisfaction at a transaction - specific level that can be measured by assorted cause - effect models. Nevertheless, there isn't a universal cause - effect model that can be used. Hence, this study combines the American Customer Satisfaction Index (ACSI) Model, the European Customer Satisfaction Index (ECSI), and another general consumer satisfaction models to construct antecedent variable of traveller's satisfaction in Lake Toba.

According to ACSI (Fornell et al., 1996), the three antecedents of customer satisfaction are customer expectations, perceptions of quality, and perceived value. Referring to the ECSI model, his customer satisfaction can be recognized by those three antecedents as well as company image. Xia et al. (2009) proposed the above three antecedents together with destination image can also be utilize as predictors of tourist satisfaction. Furthermore, Dmitrovic et al. (2009) explains that tourist satisfaction can also be determined by quality, perceived value, image along with cost and risk. In Western Australia, Quintal \& Polczynski (2010) studied the relationship between perceived attractiveness, quality perception, value perception, risk perception, and satisfaction, while in Thailand, Prayag \& Ryan (2011) investigated the role and influence of destination images, place attachments, and personal engagement on visitor satisfaction. Based on these backgrounds, the study examined five antecedents of traveller's satisfaction: traveller's expectations, perception of quality, value perception, image of destination, and cost and risk.

\subsection{Revisit Intention}

Han \& Kim (2010) expressed an intention to re-visit the tourist destination defined as the readiness of individuals to re-visit the same destination, making an accurate holiday planning. The interest in re-visiting is influenced by the level of satisfaction, perceived value, and past behaviour. According to Zeithaml et al. (2018), there are several behaviours that are raised as a person's reaction to a place, namely approach behaviour which is a positive behaviour that is driven by the dissatisfaction of a particular place in the form of a return visit, the desire to stay, explore, and affiliate. Avoidance behaviour shows the opposite, i.e., unwilling to stay, to explore, to work, and unaffiliated. There are 3 dimensions of re-visiting interest, namely:

1. Repeat Purchase - includes the desire of tourists to make future buybacks. 
HOLISTICA Vol 12, Issue 1, 2021, pp.41-48

2. Repeat Visits - includes the desire of tourists to revisit tourist destinations.

3. Recommendation - includes the desire of tourists in recommending destinations.

\section{Conceptual Framework}

Systemically, the conceptual framework that is used can be seen below:

Figure 1 Conceptual Framework

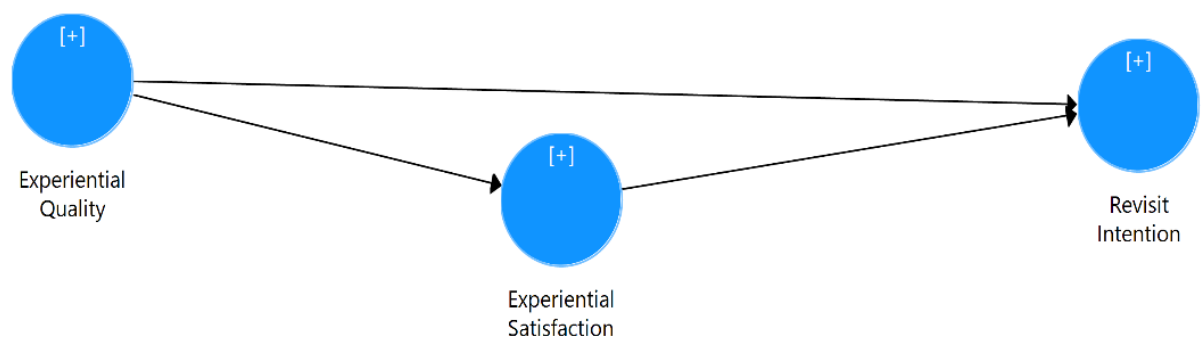

Source: Author's synthesis

\section{Hypothesis}

The hypotheses of this study are:

1. Experiential Quality has a positive and significant effect on revisit intention in Lake Toba.

2. Experiential Satisfaction has a positive and significant effect on revisit intention in Lake Toba.

3. Experiential Quality has a positive and significant effect on revisit intention through Experiential Satisfaction in Lake Toba.

\section{Research Method}

This study is based on an associative research. The place of research is in Lake Toba where the population in this study is represented by tourists who have visited Lake Toba, and, because of the large number of tourists who come, the number of populations is unknown, therefore the withdrawal of samples uses the theory from Malhotra (2010) where the number of samples must be at least four or five times the number of questions where the total number of questions from this study as many as 16 questions multiplied 
by 4 then obtained 324 tourists who have visited Lake Toba. The sampling technique in this study is accidental, where researchers take respondents as samples based on coincidence, anyone who accidentally meets with the researcher can be used as a sample when the person who happens to be encountered matches as source of data with the main criterion. The data analysis in this study is descriptive statistics and data analysis using SEM-PLS and Smart-PLS software.

\section{Results}

\subsection{Analysis of Respondent Characteristics}

Based on the characteristics of respondents, it is discovered that female respondents in this study dominate the male ones with 188 over 136 . While respondents' ranges of age are 17-23 years for 116 respondents, 24-30 years old, and 31-37 years old. The work characteristic is dominated by students and employees. Most respondents mostly come from the surrounding areas of North Sumatra namely Medan, Pematang, Siantar, Binjai, and others. Tourists' activities are consistent with visiting the site, because of their purpose of visit which is represented by recreation and spending holiday.

\subsection{PLS Model Analysis Result}

\subsubsection{Evaluation of Measurement Model (Outer Model)}

In table 1, it is observable that the outer values between all indicators are above 0.5 (outer loading > 0.5), which is therefore said to be feasible (valid) for further analysis. The composite reliability values indicate the value of each construct is above 0.7 (composite reliability > 0.7). All AVE values are above 0.5 (AVE > 0.5). Therefore, the structural equation model above has met the criteria in convergent validity.

Table 1 Outer Model

\begin{tabular}{cccc}
\hline & $\begin{array}{c}\text { Outer } \\
\text { Loading }\end{array}$ & $\begin{array}{c}\text { Composite } \\
\text { Reliability }\end{array}$ & $\begin{array}{c}\text { Average Variance } \\
\text { Extracted (AVE) }\end{array}$ \\
\hline Experiential Quality & & 0.964 & 0.772 \\
EQ1 & 0.898 & & \\
EQ2 & 0.882 & & \\
EQ4 & 0.837 & & \\
EQ5 & 0.887 & & \\
EQ6 & 0.883 & & \\
EQ7 & 0.901 & & 0.781 \\
EQ8 & 0.863 & & \\
\hline
\end{tabular}




$\begin{array}{ll}\text { ES1 } & 0.923 \\ \text { ES2 } & 0.887 \\ \text { ES3 } & 0.928 \\ \text { ES4 } & 0.789\end{array}$

Revisit Intention

0.973

0.901

$\begin{array}{ll}\text { RI1 } & 0.953 \\ \text { RI2 } & 0.959 \\ \text { RI3 } & 0.934 \\ \text { RI4 } & 0.950\end{array}$

Source: Author's synthesis

Table 2 Outer Model Measurement

\begin{tabular}{cccccc}
\hline & $\begin{array}{c}\text { Original } \\
\text { Sample } \\
(\mathrm{O})\end{array}$ & $\begin{array}{c}\text { Sample } \\
\text { Mean } \\
(\mathrm{M})\end{array}$ & $\begin{array}{c}\text { Standard } \\
\text { Deviation } \\
(\text { STDEV })\end{array}$ & $\begin{array}{c}\text { T Statistics } \\
(\mid \mathrm{O} / \text { STDEV } \mid)\end{array}$ & $\begin{array}{c}\mathrm{P} \\
\text { Values }\end{array}$ \\
\hline $\begin{array}{c}\text { Experiential_Quality -> } \\
\text { Experiential_Satisfaction } \\
\text { Experiential_Quality -> } \\
\quad \text { Revisit_Intention }\end{array}$ & 0.919 & 0.919 & 0.008 & 108.908 & 0.000 \\
$\begin{array}{c}\text { Experiential_Satisfaction -> } \\
\quad \text { Revisit_Intention }\end{array}$ & 0.798 & 0.197 & 0.065 & 3.050 & 0.001 \\
$\quad \begin{array}{c}\text { Experiential_Quality -> } \\
\text { Experiential_Satisfaction -> } \\
\text { Revisit_Intention }\end{array}$ & 0.652 & 0.710 & 0.076 & 9.379 & 0.000 \\
\hline
\end{tabular}

Source: Author's synthesis 
The tables show the following results:

1. Experiential quality has a positive and significant effect on experiential satisfaction variables, which is known from $p$-value below $0.05(0.000<0.05)$

2. Experiential quality has a positive and significant effect on variable revisit intention, which is known from the p-value below $0.05(0.001<0.05)$

3. Experiential satisfaction has a positive and significant effect on variable revisit intention, which is known from the p-value below $0.05(0.000<0.05)$

Moreover, the table also implies the following result: Experiential quality has a positive and significant effect on variable revisit intention through experiential satisfaction, which is known from p-value below $0.05(0.000<0.05)$.

\section{Discussion, and Conclusions}

The results showed that experiential quality has a positive and significant effect on experiential satisfaction variables. This result is in line with Li and Wu's theory (2013), where it is said that experiential quality is an important variable in influencing experiential satisfaction. The quality of the experience felt by tourists has been good because of this, so tourists feel the satisfaction of the experience. This is also in accordance with Chen and Chen's theory (2010) which states that if the experience felt by tourists is in accordance with expectations then tourists will be satisfied. Tourists feel Lake Toba is indeed one of the tourist destinations where one can find many new and unique experiences and knowledge not obtained elsewhere. Similarly, the influence of experiential quality on revisit intentions is known to have a positive and significant effect, where both the quality of the experience that tourists feel makes tourists want to revisit Lake Toba. Similarly, through experiential satisfaction, the influence of experiential quality on revisit intention is found to have a positive and significant influence, which shows the experience that tourists feel makes tourists satisfied and will revisit those tourist attractions. The relationship between these variables is also supported by some researches by Bigne et al., 2005; Kao et al., 2008; Li and Wu, 2013, which stated that the association between the satisfaction of the experience, the quality of the experience, and the intention of revisiting in the context of the attraction is quite rare to research. The implication of this research is that experience is an important thing to research, where good and bad experiences can make tourists revisit tourist attractions. Experience in this research is important and must be further developed because many aspects are influenced by experience and of course there are many things that can be researched when discussing tourism.

\section{Acknowledgement (if it is necessary)}

We thank the Directorate of Research and Community Service from the Ministry of Education and Culture of the Republic of Indonesia for financing this research from the "Higher Education Excellent Basic Research Grant Fund" program. 


\section{References}

Bigne, J.E., Andreu, L., \& Gnoth, J. (2005). The theme park experience: An analysis of pleasure, arousal and satisfaction. Tourism Management, 26, 833-844.

Chen, C.F., \& Chen, F.S. (2010). Experience quality, perceived value, satisfaction and behavioral intentions for heritage tourists. Tourism Management, 31, 29-35.

Crompton, J.L., \& Love, L.L. (1995). The predictive validity of alternative approaches to evaluating quality of a festival. Journal of Travel Research, 34, 11-24.

Cronin, J.J., \& Taylor, S.A. (1994). SERVPERF versus SERVQUAL: Reconciling performance-based and perceptions-minus-expectations measurement of service quality. Journal of Marketing, 58(1), 125-131.

Dmitrovic, T., Cvelbar, L., Kolah, T., Brencic, M., Ograjensek, I., \& Zabkar, V. (2009). Conceptualizing Tourist satisfaction At the Destination Level. International Journal of Culture. Tourism and Hospitality Research, 3(2), $116-126$.

Fornell, C., Johnson, M.D., Anderson, E.W., Cha, J., \& Bryant, B.E. (1996). The American customer satisfaction index: Nature, purpose, and findings. Journal of Marketing, 60(4), 7-18.

Han, H., \& Kim, Y. (2010). An investigation of green hotel customers' decision formation: Developing an extended model of the theory of planned behavior. International Journal of Hospitality Management, 29(4), 659-668.

Kaimasu, M. (2020). CONSUMERS' ELECTRICITY CONSUMPTION BEHAVIOUR AND POWER UTILITIES' PREFERENCES. Review of Behavioural Aspect in Organizations and Society, 2(1), $1-14$.

Kao, Y.F., Huang, L.S., \& Wu, C.H. (2008). Effects of theatrical elements on experiential quality and loyalty intentions for theme parks. Asia Pacific Journal of Tourism Research, 13, 163-174.

Li, M.Y., \& Wu, H.C. (2013). An empirical study of visitors' behavioral intentions in the theme park: The case of Zhu-Hai. Paper presented at the 2013 International Conference on Tourism Industry and Education, Taoyuan, Taiwan.

Malhotra, N.K. (2010). Marketing Research: An Applied Orientation. Prestige Hall: United State of America.

Prayag, G. (2008). Image, Satisfaction and Loyalty: The Case of Cape Town. Anatolia: An International Journal of Tourism and Hospitality Research, 19 (2): 205-224

Quintal, V.A., \& Polczynski, A. (2010). Factors Influencing Tourists' Revisit Intentions. Asia Pacific Jour- nal of Marketing and Logistics, 22(4), 564-578.

Ranathilaka, M.B., Lashmi, N., \& Atukorala, W. (2019). PRODUCTION AND MARKETING OF BANANA: ESTIMATING THE PROFITABILITY USING WALAWA REGION IN SRI LANKA. JBFEM, 2(1), 23-32.

Severt, D., Wong, Y., Chen, P., \& Breiter, D. (2007). Examining the motivation, perceived performance and behavioral intentions of convention attendees: Evidence from a regional conference. Tourism Management, 28 (2), 399-408.

Zeithmal, V.A, Bitner, M..J., \& Gremler, D.D. (2018). Services Marketing: Integrating Customer Focus Across the Firm. Seventh Edition. Mcgraw-Hill Education. 